\title{
HuMANITAS AND SEVERITAS On Possible Impact of Christianity on Roman Criminal LAW IN $4^{\text {TH }}$ CENTURY
}

The $4^{\text {th }}$ century is undoubtedly the period of far-reaching transformations, not only in the organisation and functions of the Roman State but also in the domain of culture and economy. The deepest change, however, took place in the religious domain. Within shorter than a hundred years, persecuted Christianity essentially became a state religion. Presumably such a radical change had to leave its mark on all domains of social activity, including criminal law of that era. ${ }^{1}$ Therefore, the purpose of this

* M.A., Teaching Assistant, Maria Curie-Skłodowska University in Lublin; e-mail: bartosz.zalewski@poczta.umcs.lublin.pl,ORCIDID:https:/ / orcid.org/0000-0001-7508-354X.

1 The issue of the impact of Christianity on Roman law is not new, and has already been addressed by many studies. The work on Christian inspiration for the transformation of the Roman private law was already published in the mid- $19^{\text {th }}$ century by R.T. Troplong, De l'influence du christianisme sur le droit civiles des Romains, Paris 1855. Further studies date back to the beginning of the $20^{\text {th }}$ century, mainly but not exclusively of a contributory nature, which, by the way, have led to diverse research conclusions, cf. e.g.: E. Carusi, Diritto romano e patristica, in: Studi giuridici in onore di Carlo Fadda pel 25. anno del suo insegnamento, vol. 2, Napoli 1906, pp. 71-97; S. Riccobono (Sr.), Influenza del Cristianesimo sulla codificazione di Giustiniano, Scientia 1909, vol. 5, no. 3, pp. 122-152; idem, Cristianesimo e diritto privato, Rivista del Diritto Civile 1911, no. 3, pp. 37-70; G. Baviera, Concetto e limiti dell'influenza del Cristianesimo sul diritto romano, in: Mélanges P.F. Girard, vol. 1, Paris 1912, pp. 67-121; C. Gray, Il diritto nel Vangelo e l'influenza del cristianesimo sul diritto romano, Torino 1922; A. Marchi, Dell'influenza del cristianesimo sulla Codificazione Giustinianea, Studi Senesi 1924, vol. 38, pp. 61-103. A special place in the research on the influence of Christianity on Roman law must be given to two scholars who published their most important works in the 1950s, namely B. Biondi and J. Gaudemet. Biondo Biondi published a monumental, grand-scale study Il diritto romano cristiano (vol. 1-3, Milano 1952-1954), which constituted the opus vitae of this author. So far, no one has studied issues related to the influence of Christianity on Roman law in an equally broad perspective, although it should be noted 
article is to identify possible "directions" of the influence of Christianity on the legislative policy on criminal repression carried out by Roman emperors in the $4^{\text {th }}$ century.

Eminent Polish historian Ludwik Bazylow, when beginning to write the history of the world in the $19^{\text {th }}$ century, first had to ask himself about the chronological framework of his study. ${ }^{2}$ The first and fundamental issue was therefore to determine whether he should focus on the "short" or "long" $19^{\text {th }}$ century? A similar question must be asked by anyone who wishes to deal with any aspect of Roman history in the $4^{\text {th }}$ century and the answer will vary depending on the selection of the subject matter. For example, from the point of view of political history, it would be possible to speak of a "shifted" and "long" century, begun by Diocletian assuming power in 284 and concluded by the division of the empire between the sons of Theodosius the Great in $395 .^{3}$

that this work has certain shortcomings, mainly related to a rather superficial and intuitive analysis of many sources, which had led to the thesis that Christianity had a fundamental impact on almost all legal changes that had occurred since the $4^{\text {th }}$ century. It is worth mentioning that B. Biondi paid a lot of attention to the issues of criminal law and procedure (ibidem, vol. 3, pp. 413-518). Jean Gaudemet expressed his views primarily in his work La formation du droit séculier et du droit de l'Église aux IVe et Ve siècles (Paris 1957) and in a comprehensive synthesis on the history of the organisation of the Church in the Roman Empire in the $4^{\text {th }}$ and $5^{\text {th }}$ centuries - L'Église dans l'Empire romain (IV-V siècles) (Paris 1958). Jean Gaudemet's concept, especially against the background of the views promoted by B. Biondi, remains moderate and is characterised by a more cautious evaluation of the source materials. In the countries under the domination of the Soviet Union, the study of the influence of Christianity on Roman law was led by the Polish scholar, B. Łapicki, who in his studies: Etyczna kultura starożytnego Rzymu a wczesne chrześcijaństwo (WrocławŁódź 1958) and O spadkobiercach ideologii rzymskiej. Okres chrystianizacji cesarstwa rzymskiego (Eódź 1962) applied the methodology of Marxist historical materialism (cf. M. Kaser, Borys Łapicki. Etyczna kultura starożytnego Rzymu a wczesne chrześcijaństwo (La culture éthique de la Rome ancienne et les premiers temps du christianisme). Łódź, Ossolinski, 1958. 322 S. [review], Zeitschrift der Savigny-Stiftung für Rechtsgeschichte. Romanistische Abteilung [1959], vol. 76, pp. 656-657) of course significantly affected the theses proposed by the author. Out of more recent works on this issue it is worth first of all to underline the work by A. Dębińs$\mathrm{ki}$, addressing the issue of Christianity and Roman law in the wide historical panorama: Church and Roman Law (transl. K. Szulga, Lublin 2010), and the collection of D. Liebs' articles: Das Recht der Römer und die Christen (Tübingen 2015).

2 L. Bazylow, Historia powszechna 1789-1918, Warszawa 1981, p. 13.

3 This chronological description of the history of the Roman empire was adopted for example by the authors of the collective work: Świat rzymski w IV w., ed. P. Filipczak, R. Kosiński, Kraków 2015. 
However, when reflecting on the influence of Christianity on Roman law in the $4^{\text {th }}$ century, the chronology must be outlined somewhat differently. The starting date may be the issuance of the Edict of Milan by Constantine the Great and Licinius in 313. ${ }^{4}$ This was not the first "edict of toleration", but it certainly remains the most important and famous one. ${ }^{5}$ The final date will be the publication of the Constitution Cunctos populos of 380 by Gratian, Theodosius the Great and Valentinian II, which de facto established Christianity as the state religion in the formula adopted in Nice, referred to as Catholic. ${ }^{6}$ Therefore, the discussion herein will cover the "short" $4^{\text {th }}$ century.?

During this period, relations defined conventionally as "relations between the State and the Church," or perhaps more correctly, between secular and clerical authorities, have also undergone an interesting evolution. ${ }^{8}$ In a work written immediately after the death of Constantine the Great, known as Vita Constantini, Eusebius of Caesarea postulated a model of relations, which is sometimes associated with later caesaropapism. ${ }^{9}$ In this

4 Cf. Lact., De mort. pers. 48; Eusebius, Hist. Ecc. 10,5,2-14.

5 Earlier an edict was issued by Emperor Galerius in 311 - J. Gaudemet, L'Église..., pp. 8-9; S. Bralewski, Kościót w świecie rzymskim w IV wieku, in: Świat rzymski w IV w., ed. P. Filipczak, R. Kosiński, Kraków 2015, p. 313; R. Paribeni, Storia di Roma, vol. 8. Da Diocleziano alla caduta dell'impero d'occidente, Bologna 1941, p. 70 (with the indication of the date of Galerius' Edict in A.D. 310).

6 C. Th. 16,1,2: pr. Cunctos populos, quos clementiae nostrae regit temperamentum, in tali volumus religione versari, quam divinum petrum apostolum tradidisse Romanis religio usque ad nunc ab ipso insinuata declarat quamque pontificem Damasum sequi claret et Petrum Alexandriae episcopum virum apostolicae sanctitatis, hoc est, ut secundum apostolicam disciplinam evangelicamque doctrinam patris et filii et spiritus sancti unam deitatem sub parili maiestate et sub pia trinitate credamus. 1. Hanc legem sequentes christianorum catholicorum nomen iubemus amplecti, reliquos vero dementes vesanosque iudicantes haeretici dogmatis infamiam sustinere nec conciliabula eorum ecclesiarum nomen accipere, divina primum vindicta, post etiam motus nostri, quem ex caelesti arbitrio sumpserimus, ultione plectendos.

7 Cf. R. Paribeni, Storia di Roma, vol. 8, pp. 328-329.

8 Synthetic characteristics is provided e.g. by: J. Gaudemet, L'Église..., pp. 9-14; R. Paribeni, Storia di Roma, vol. 8, pp. 329-330; B. Kumor, Historia Kościoła, vol. 1. Starożytność chrześcijańska, Lublin 1973, pp. 127 ff.; M. Wójcik, Cesarz w Kościele czy ponad Kościołem? Relacje między imperium a sacerdotium w IV wieku, in: Romanitas et Christianitas. Stanislao Płodzień (1913-1962) in memoriam, ed. A. Dębiński, S. Jóźwiak, Lublin 2008, pp. 279-298.

9 Cf. D.J. Geanakoplos, Church Building and "Caesaropapism," A.D. 312-565, Greek, Roman and Byzantine Studies 1966, vol. 7, no. 2, pp. 167-186. Carl Schmitt remained sceptical on associating Eusebius with the concept of caesaropapism: Politische Theologie II. Die 
model, the emperor is the guardian and, to some extent, even the superior of the Church described as the "universal bishop" (koinós episkopos - kovvós غंпібкопо ). ${ }^{10}$ For a ruler claiming to be the "supreme priest" (pontifex maximus) of the pagan religion, ${ }^{11}$ who perhaps personally had the opportunity to see the ceremonies at the court of Diocletian identified with Jupiter, the protectorate of the monarch over the Church had to be completely natural. ${ }^{12}$ However, as early as under the reign of the sons of Constantine, opposition was growing against this state of affairs, which the Emperor Constantius II, recognising himself as the head of the Church and at the same time advocating Arianism, attempted to maintain. ${ }^{13}$ In the second half of the century, the situation was so different that St. Ambrose, the Bishop of Milan, could afford to refuse to give Holy Communion to Theodosius the Great himself, who had ordered the massacre of the people of Thessalonica who were committing tumults. ${ }^{14}$

It is worth noting that the notion of humanitas, referred to in the title of this study, also underwent a deep evolution in the $4^{\text {th }}$ century. Humanitas, which originally meant not only a certain humanitarianism or gentleness, but also good manners and education, ${ }^{15}$ became a subject of keen interest

Legende von der Erledigung jeder Politischen Theologie, Berlin 2017, pp. 54 ff. Likewise M. Wójcik, but stating that Eusebius "laid theoretical foundations for the doctrine of caesaropapism," cf. M. Wójcik, Cesarz w Kościele..., pp. 279, 282.

10 Eusebius, Vita Const. 1,44. The emperor reportedly used also to refer to himself as

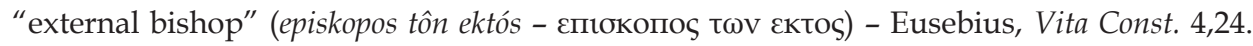
Eusebius recognized him as a pee to the apostles (isapostolos - Iбanóotolos) - Eusebius, Vita Const. 4,58 and 4,70-71. Cf. also R. Farina, L'Impero e l'Imperatore cristiano in Eusebio di Cesarea. La prima teologia politica del cristianesimo, Roma-Zürich 1966, pp. 236 ff.

11 T.D. Barnes, Constantine and Eusebius, London 1996, p. 245.

12 Cf. P. Veyne, Qu'était-ce qu'un empereur romain?, Diogène 2002, vol. 199, no. 3, pp. 3-25.

13 Cf. R. Paribeni, Storia di Roma, vol. 8, pp. 130 ff.; M. Wójcik, Cesarz w Kościele..., pp. 286-290; E. Wipszycka, Kościót w świecie późnego antyku, Warszawa 1994, pp. 163 ff. Broadly on the Constantius' religious policy cf. T.D. Barnes, Athanasius and Constantius. Theology and Politics in the Constantinian Empire, London 2001, passim.

14 A. Cameron, Późne cesarstwo rzymskie, transl. M. Kwiecień, Warszawa 2005, p. 92.

15 On the notion of humanitas, see especially: H. Krüger, Die humanitas und die pietas nach den Quellen des römischen Rechtes, Zeitschrift der Savigny-Stiftung für Rechtsgeschichte. Romanistische Abteilung 1898, vol. 19, no. 1, pp. 6-57; R. Harder, Nachträgliches zu humanitas, Hermes 1934, vol. 69, pp. 64-74; C.A. Maschi, "Humanitas" come motivo giuridico, in: Scritti in memoria di Luigi Cosattini, Trieste 1948, pp. 263-362; F. Beckmann, Humanitas: Ursprung und Idee, Münster 1952, passim; B. Biondi, Il diritto romano cristiano, vol. 2, 
on the part of Christian intellectuals, the most important of whom must be Lactantius and the aforementioned Ambrose of Milan. ${ }^{16}$ As B. Biondi rightly states, they have given this idea an ethical and religious flavour, which is essentially not found in pagan writings. ${ }^{17}$ Lactantius identified humanitas with misericordia, ${ }^{18}$ referring it to various domains of human

Milano 1952, pp. 150 ff.; S. Riccobono (Jr.), L'idea di "humanitas" come fonte di progresso del diritto, in: Studi in onore di Biondo Biondi, vol. 2, Milano 1965, pp. 583-614; H. Kupiszewski, Humanitas a prawo rzymskie, Prawo Kanoniczne. Kwartalnik Prawno-Historyczny 1977, vol. 20, pp. 277-294 (= idem, Prawo rzymskie a wspótczesność, Kraków 2013, pp. 239-266); F.B.J. Wubbe, L'"humanitas" de Justinien, Tijdschrift voor Rechtsgeschiedenis 1990, vol. 58, no. 3, pp. 249-262; A. Palma, Humanior interpretatio: "Humanitas" nell'interpretazione e nella normazione da Adriano ai Severi, Torino 1992, passim; P. Veyne, Humanitas: Romans and Non Romans, in: The Romans, ed. A. Giardina, transl. L. Cochrane, Chicago 1993, pp. 342-369; R. Bauman, Human Rights in Ancient Rome, London-New York 2003; L. Garofalo, L'"humanitas" nel pensiero della giudisprudenza classica, in: L'humanitas nel mondo antico: filantropia, cultura, pietas. Convegno nazionale di studi, Chiesa S. Croce in San Leonardo all'Università, 22 novembre 2003, Treviso 2003, pp. 27-43; G. Purpura, Brevi riflessioni sull'"humanitas", Annali del Dipartimento di Storia del Diritto dell'Università di Palermo 2009, vol. 53, pp. 289-298; A. Balbo, Humanitas in First Century AD: Seneca and Quintilian, The Journal of Greco-Roman Studies 2012, vol. 47, pp. 63-93; T.P. Scheck, Humanitas in Cicero's Moral Philosophy and Its Christian Reception, Ave Maria Law Review 2012, vol. 10, no. 2, pp. 405-415; M. Frare, L'humanitas romana. Vessillo del potere imperiale, Padova 2013, passim; J.G. Hruşcă, Humanitas Romana and Edictum Mediolanense. Inter-Conditionalities and Transitions for the Benefit of Equity and Tolerance, International Journal of Communication Research 2013, vol. 3, no. 2, pp. 166-170; L. Garofalo, L' "humanitas" tra diritto romano e totalitarismo hitleriano, Zeszyty Prawnicze 2015, vol. 15, no. 2, pp. 43-75; A. Tarwacka, O tym, że termin "humanitas" nie oznacza tego, co się powszechnie sądzi, natomiast ci, którzy mówili czystszym językiem, używali go bardziej wtaściwie. Aulus Gellius, "Noce attyckie" 13,17. Tekst - tłumaczenie - komentarz, Zeszyty Prawnicze 2015, vol. 15, no. 2, pp. 243-248; M. Merkwa, U źródet idei praw człowieka. Ksztattowanie prawnych i filozoficznych podstaw koncepcji praw człowieka, Lublin 2018, pp. 63-66. Cf. e.g.: Gell., Noct. Att. 13,17,1-4.

${ }_{16}$ Cf. B. Łapicki, O spadkobiercach..., p. 9. These were not the first Christian writers who referred to this notion. Humanitas was often invoked especially by Minucius Felix in the dialogue "Octavius" - cf. e.g.: Min., Oct. 8; 17; 26.

17 B. Biondi, Il diritto romano cristiano, vol. 2, p. 153.

18 Lact., Div. Inst. 6,10,1-2: Dixi, quid debeatur Deo: dicam nunc, quid homini tribuendum sit; quanquam id ipsum quod homini tribueris, Deo tribuitur, quia homo Dei simulacrum est. Sed tamen primum officium justitiae est, conjungi cum Deo; secundum, cum homine. Sed illud primum, Religio dicitur; hoc secundum, misericordia vel humanitas nominatur. Quae virtus propria est justorum et cultorum Dei; quod ea sola vitae communis continet rationem. See also: B. Colot, Humanitas et ses synonymes chez Lactance, in: Les Problèmes de la synonomie en Latin, ed. C. Moussy, Paris 1992, p. 104. The author argues that in the Lactantius' views iustitia 
conduct, including both private and public life. ${ }^{19}$ Humanitas, according to Lactantius, should determine altruistic behaviour ${ }^{20}$ such as helping the poor and needy, burying the dead etc. ${ }^{21}$

In the works of St. Ambrose, this notion has even stronger religious connotations. The Bishop of Milan was deriving the word homo from humus (soil), ${ }^{22}$ perhaps referring to one of the biblical descriptions of the creation of man, ${ }^{23}$ which is to translate - according to B. Eapicki - to the Ambrosian etymology of humanitas. ${ }^{24}$ Ambrose emphasises that humanitas is a human virtue and at the same time an imperative of the law of nature, according to which one should help other people as if they were all members of one body..$^{25}$ On the one hand, there is noticeable influence of the concept of Lactantius, according to which humanitas was a virtue based on natural law, and on the other, Ambrose clearly referred to St. Paul, who stated: "For we were all baptised by one Spirit so as to form one body." ${ }^{26}$ It is worth noting that humanitas was also the ground for the criticism of

constitutes a basis for humanitas, pietas and misericordia. In turn, S. Riccobono Jr. stated that humanitas in the Lactantius' views is an equivalent of misericordia and iustitia, cf. S. Riccobono Jr., L'idea di "humanitas"..., p. 611.

19 Cf. Lact., Div. Inst. 6,10-11.

20 Lact., Div. Inst. 6,12, 2: Tenendum est igitur omni modo, ut ab officio misericordiae spes recipiendi absit omnino: hujus enim operis et officii merces a Deo est expectanda solo: nam si ab homine expectes, jam non humanitas erit illa, sed beneficii foeneratio; nec potest videri bene meruisse, qui quod facit, non alteri, sed sibi praestat.

21 Lact., Div. Inst. 6,11,4-7.

22 Ambrosius, De off. min. 3,3,16: Considera, o homo, unde nomen sumpseris; ab humo utique, quae nihil cuiquam eripit, sed omnia largitur omnibus, et diversos in usum omnium animantium fructus ministrat. Inde appellata humanitas specialis et domestica virtus hominis, quae consortem adiuvet.

${ }^{23}$ Genesis 2:5-7.

24 B. Łapicki, O spadkobiercach..., p. 53.

25 Ambrosius, De off. min. 3,3,19: Haec utique lex naturae est, quae nos ad omnem astringit humanitatem, ut alter alteri tamquam unius partes corporis invicem deferamus. Nec detrahendum quidquam putemus, cum contra naturae legem sit non iuvare. Sic enim nascimur ut consentiant membra membris, et alterum alteri adhaereat, et obsequantur sibi mutuo ministerio.

261 Corinthians 12:13. Cf. Ambrosius, De off. min. 3,3,19: Si pedem vulneret, quantorum sibi actuum profectum inviderit? Et quanto gravius est totum hominem quam unum membrum detrahi? Iam si in uno membro totum corpus violatur, utique in uno homine communio totius humanitatis solvitur; violatur natura generis humani, et sanctae Ecclesiae congregatio, quae in unum connexum corpus atque compactum unitate fidei et charitatis assurgit: Christus quoque Dominus, qui pro universis mortuus est, mercedem sanguinis sui evacuatam dolebit. 
collecting interest on loans. ${ }^{27}$ However, Ambrose generally paid much less attention to it than Lactantius did. Both Christian authors identified humanitas and misericordia, which were distinguished by some pagan writers such as Pliny the Younger. ${ }^{28}$

In opposition to the notion of humanitas, of course, there is a certain severity (severitas) and even cruelty (crudelitas). It is not surprising that those notions did not have a theoretical foundation similar to that behind humanitas, nevertheless the very issue of the severity of penalties was undertaken by those authors, both in the context of punishment for sins and punishment for public crimes. One can point here, for example, to the works of Lactantius, such as De ira Dei or De mortibus persecutorum, in which the concept of severe punishment for committed sins was clearly visible. It should be stressed however, that Lactantius was at the same time a strong opponent of the death penalty and even bringing charges in cases where this penalty could be imposed. ${ }^{29}$

Referring to the later views of Christian authors on the relationship between guilt and punishment, it is worth noting after P. Garnsey that St. Ambrose, although he recommended a judge, who was the addressee of one of his letters, to be moderate in sentencing, did not postulate the abolition of the death penalty at all..$^{30}$ In the collection known as Apostolic Constitutions (Constitutiones Apostolorum), dating back to the $4^{\text {th }}$ or the beginning of the $5^{\text {th }}$ century, the death penalty was allowed to be applied to criminals, provided that it was imposed by an authorised public authority. ${ }^{31}$

Therefore, the term "influence of Christianity on the Roman criminal law" should be understood mostly as the influence that could have

27 Cf. Ambrosius, De off. min. 3,3,20.

28 Cf. Plin., Pan. 3: Non enim periculum est, ne, quum loquar de humanitate, exprobrari sibi superbiam credat; quum de frugalitate, luxuriam; quum de clementia, crudelitatem; quum de liberalitate, avaritiam; quum de benignitate, livorem; quum de continentia, libidinem; quum de labore, inertiam; quum de fortitudine, timorem. Pliny considers humanitas as an opposite to pride (superbia), not cruelty (crudelitas).

29 Lact., Div. Inst. 6,20,16-17: Ita neque militare justo licebit, cujus militia est ipsa justitia; neque vero accusare quemquam crimine capitali: quia nihil distat utrumne ferro, an verbo potius occidas; quoniam occisio ipsa prohibetur. Itaque in hoc Dei praecepto nullam prorsus exceptionem fieri oportet, quin occidere hominem sit semper nefas, quem Deus sanctum animal esse voluit.

30 P. Garnsey, Why Penalties Become Harsher: The Roman Case, Late Republic to Fourth Century Empire, Natural Law Forum 1968, 1/1, pp. 155-156.

31 A. Dębiński, Kara śmierci w świetle literatury wczesnochrześcijańskiej, in: Religia i prawo karne w starożytnym Rzymie, ed. A. Dębiński, M. Kuryłowicz, Lublin 1998, p. 49. 
been exerted by certain intellectual concepts of Christian authors living in the $4^{\text {th }}$ century as well as the mutual influence of secular law and disciplinary norms adopted by episcopal synods. ${ }^{32}$ Attempts to assess that influence from the perspective of the then Christian customs would probably be more difficult to verify, although even this task - based most often on indirect sources or short mentions - would probably be plausible. ${ }^{33}$

The first and fundamental question of course concerns the scale of the phenomenon. It seems that, contrary to the "programmatic optimism" presented by B. Biondi, the impact of Christianity on Roman law cannot be overestimated. This impact was modest to the extent of criminal repression and emergence of new types of crimes. In the enormous number of imperial constitutions, a small fraction of which has presumably survived to our time, there are relatively few where Christian inspirations are likely to impact. In substantive terms, they relate mainly to religious matters and are characterised by the severity of criminal law of that era. Relatively few constitutions connected with the alleviation of criminal repression are generally also attributable to Christian influence, sometimes intersecting with other aspects, often of a procedural and political-propaganda nature. It is worth noting that the thesis proposed by E. Volterra, that some of imperial constitutions from the period in question could have been developed not by lawyers from the imperial chancellery but by clerics at the ruler's court, is quite reasonable. ${ }^{34}$

Those certainly include the prohibition of face stigmatising (or rather tattooing) of people sentenced to work in mines (opus metalli) or to arena performance after training in a gladiatorial school (damnatio in ludum), issued by Constantine the Great. ${ }^{35}$ There was no tendency to alleviate those

32 Cf. J. Gaudemet, La formation..., pp. $178 \mathrm{ff}$.

33 A kind of "bodacious" analysis - on a side note of the Constitution C. Th. 9,24,1 of the Constantine the Great - was carried out by J. Evans-Grubbs, who reconstructed Christian customs, taking into account not only the content of the canons of synods of that time but also by taking into account some of the customs that preserved in the rural communities of the Mediterranean, cf. J. Evans-Grubbs, Abduction Marriage in Antiquity: A Law of Constantine (CTh IX. 24. 1) and Its Social Context, The Journal of Roman Studies 1989, vol. 79, pp. 59-83.

34 E. Volterra, Quelques remarques sur le style des constitutions de Constantin, in: Droits de l'Antiquité et sociologie juridique:Mélanges Henri Lévy-Bruhl, Paris 1959, p. 334.

${ }_{35}$ C. Th. 9,40,2: Si quis in ludum fuerit vel in metallum pro criminum deprehensorum qualitate damnatus, minime in eius facie scribatur, dum et in manibus et in suris possit poena damnationis una scriptione comprehendi, quo facies, quae ad similitudinem pulchritudinis caelestis est 
penalties during the pagan period, and the expression facies, quae ad similitudinem pulchritudinis caelestis est figurate in the constitution strongly suggests Christian influences. However, the territorial scope of applicability of the constitutions which imposed this regulation was unclear. It was addressed to the Vicar of Africa and was probably originally applicable only in the area of the African Diocese. ${ }^{36}$

The Christian inspiration may also be attributed to the prohibition of the use of the aforementioned damnatio in ludum in the Eastern Prefecture proclaimed by Constantine in A.D. $325 .{ }^{37}$ Preserved accounts of Eusebius of Caesarea suggest that it was a part of a broader legislative action of this ruler after having overthrown Licinius. ${ }^{38}$ It must be associated primarily with the critical stance of Christian authors, such as Tertullian and Lactantius, towards damnatio in ludum. ${ }^{39}$ That punishment was perceived by them not only as disproportionately harsh in relation to the offences but also morally detrimental to the audience who "participated" in

figurata, minime maculetur. See also: F. Salerno, "Minime in ... facie scribatur": Constantine and the "damnati ad metalla", in: Esclavage antique et discriminations socio-culturelles, ed. V.I. Anastasiadis, P.N. Doukellis, Berne-New York 2005, pp. 329 ff.; J. Wiewiorowski, The Judiciary of Diocesan Vicars in the Later Roman Empire, transl. S. Nowak, Poznań 2015, pp. 170-171; B. Zalewski, Inspiracje filozoficzne i religijne dla zakazu piętnowania twarzy skazańców. Ze studiów nad konstantyńska humanitas, Czasopismo Prawno-Historyczne 2017, vol. 69, no. 2, pp. 313 ff.

36 B. Zalewski, Inspiracje filozoficzne..., p. 315.

37 C. Th. 15,12,1: Cruenta spectacula in otio civili et domestica quiete non placent. Quapropter, qui omnino gladiatores esse prohibemus eos, qui forte delictorum causa hanc condicionem adque sententiam mereri consueverant, metallo magis facies inservire, ut sine sanguine suorum scelerum poenas agnoscant. This constitution was subject to keen interest among scholars, cf. e.g.: P. Sadowski, Constantin le Grand et les gladiateurs. Autour de la constitution impériale affichée à Beyrouth (C. Th. 15,12,1), Niš and Byzantium: Twelfth Symposium, Niš, 3-6 June 2013 [the collection of scientific works XII] Niš 2014, pp. 545 ff.; P. Kubiak, Damnatio ad bestias i inne kary wykonywane na arenie w antycznym Rzymie, Łódź 2014, pp. 129-131; D. Potter, Constantine and the Gladiators, Classical Quarterly 2010, vol. 60, no. 2, pp. 596-606.

38 Cf. Eusebius, Vita Const. 2,45 and 4,25. It seems that both fragments refer to the same period.

39 Tertulianus, De spectaculis 19,4: Certe quidem gladiatores innocentes in ludum veneunt, ut publicae voluptatis hostiae fiant. etiam qui damnantur in ludum, quale est ut de leviore delicto in homicidas emendatione proficiant? Lact., Div. Inst. 6,20,10-11: Nam qui hominem, quamvis ob merita damnatum, in conspectu suo jugulari pro voluptate computat, conscientiam suam polluit, tam scilicet, quam si homicidii, quod fit occulte, spectator et particeps fiat. Hos tamen ludos vocant, in quibus humanus sanguis effunditur. Adeo longe ab hominibus secessit hamanitas; ut cum animas hominum interficiant, ludere se opinentur, nocentiores iis omnibus, quorum sanguinem voluptati habent. 
the flagitious spectacle. The criticism of the punishment in ludum by Christian writers was also a part of a broader phenomenon, namely the intrinsic Christian aversion to the bloody gladiatorial games (and other spectacles) in general. ${ }^{40}$ However, they were certainly not abolished in the $4^{\text {th }}$ century because there are historical accounts according to which those spectacles were being held in the western part of the empire even in the $5^{\text {th }}$ century. ${ }^{41}$

It is also highly probable that it was under the influence of Christianity that the first attempts to improve the conditions of serving the sentence of imprisonment appeared in the $4^{\text {th }}$ century. ${ }^{42}$ This is evidenced not only by the fact that those issues were previously outside the interest of the legislator but also by the involvement of clergy in helping prisoners, which at the beginning of the $5^{\text {th }}$ century took an institutionalised and legally sanctioned form. ${ }^{43}$ Nevertheless, it should be kept in mind that the pos-

40 G. Ville, La gladiature en Occident des origines à la mort de Domitien, Rome 1981, p. 465; R. Kamienik, "Moritur et ridet" w zwiazku z 1500 rocznica (476-1976) upadku Cesarstwa Zachodniorzymskiego, Roczniki Lubelskie 1979, vol. 21, pp. 35 ff. Cf. also: P. Veyne, Païens et chrétiens devant la gladiature, Mélanges de l'École Française de Rome 1999, vol. 111, no. 2, pp. 883-917.

${ }^{41}$ Cf. especially R. Kamienik, "Moritur et ridet"..., pp. 39 ff.

42 Cf. C. Th. 9,3. As far as the legal acts preserved under this title are concerned, cf. in particular: C. Kunderewicz, Traktowanie więźniów w konstytucjach cesarskich z okresu dominatu, Prawo Kanoniczne. Kwartalnik Prawno-Historyczny 1977, vol. 20, no. 3/4, pp. 283-291; A. Świętoń, Humanitaryzm w rzymskim późnoantycznym ustawodawstwie cesarskim na przykładzie konstytucji zamieszczonych w CTh 9.3. "De custodia reorum", Studia Prawnoustrojowe 2009, vol. 9, pp. 43-54. Numerous authors point to the lawmaker's motivation about the idea of humanitas, cf.: J. Hillner, Prison, Punishment and Penance in Late Antiquity, Cambridge 2015, pp. 93 ff.; J.L. Zamora Manzano, La administración penitenciaria en el derecho romano. Gestión, tratamiento de los reclusos y mejora de la custodia carcelaria, Madrid 2015, pp. 95 ff.; idem, Algunas particularidades en torno a la influencia de la misericordia y la humanidad en las fuentes romanas, Vergentis 2017, no. 4, pp. 297 ff. Cf. also A. Lovato, Il carcere nel diritto penale romano. Dai Severi a Giustiniano, Bari 1994, pp. 172-173.

43 In the constitution of emperors Honorius and Theodosius II of A.D. 419, clergymen were granted the right to enter prisons and treat ill inmates and provide prisoners with food as well as to intervene for them - Srim. 13: Convenit, nostris praescita temporibus ut iustitiam inflectat humanitas. Nam cum plerique vim fortunae saevientis aufugerint adque ecclesiasticae defensionis munimen elegerint, patiuntur inclusi non minorem quam vitavere custodiam: nullis enim temporibus in luce vestibuli eis aperitur egressus. Adque ideo quinquaginta passibus ultra basilicae fores ecclesiasticae venerationis sanctitas inhaerebit. Ex quo loco quisque tenuerit exeuntem, sacrilegii crimen incurrat. Nihil enim confugientibus miserationis impenditur, si aura liberior negatur adflictis. Eam quoque sacerdoti concedimus facultatem, ut carceris ope miserationis aulas introeat, medicetur aegros, alat pauperes, consoletur insontes et cum singulorum causas scrutatus 
tulates of pagan intellectuals, such as Libanius, which appeared in this period were completely in line with those of Christians. ${ }^{44}$ However, both the large number of constitutions issued by emperors and the very fact that Libanius, around A.D. 386, could still provide a drastic description of prison conditions, evidence the low effectiveness of subsequent imperial interventions.

The influence of Christianity certainly led to abolishing the penalty of crucifixion. ${ }^{45}$ However, there is no preserved constitution that would have clearly decided not to impose this punishment. Aurelius Victor attributed the authorship of this decision to Constantine ${ }^{46}$ but it seems that in reality it was a gradual process, which may be suggested by St. Augustine's comment that the penalty of cross was abolished by "believer-emperors" (principes credentes). ${ }^{47}$ The silence of Eusebius of Caesarea is also telling here, as he does not mention the ruler forbidding its use. In addition, there is at

agnoverit, interventiones suas apud iudicem competentem pro iure moderetur. Scimus enim idque crebris aditionibus supplicatum frequenter ideo plerosque in custodiam detrudi, ut adeundi iudicis libertate priventur et, cum semel coeperit humilior persona pati custodiam, antequam causa sciatur, iniuriae poneam sustinere compellitur. Confestim duas auri libras fico nostro contumax solvet officium, si sacerdotem negotia tam sancta curantem ianitor feralis excluserit. It is worth noting that the emperors directly invoked humanitas with the intention to mitigate severe justice. Cf. also C. Kunderewicz, Traktowanie więźniów..., p. 288.

${ }^{44}$ Cf. Libanios, Orat. 45. Cezary Kunderewicz approached this question as follows: "The striving to make Roman law improve the situation of prisoners was initiated by the Church, whose maxims were 'charity, compassion and consolation.' Unlike other religious communities, the Church tried to provide practical help in life's calamities. The Church's activities in defence of prisoners met acceptance from pagan intellectuals. But whereas the Church has sufficient strength to persuade the emperors to issue humanitarian constitutions, pagan advocates of humanitas were confining themselves to rhetoric protests only among themselves: the Libanios' speech on prisoners was not actually delivered to the public" - C. Kunderewicz, Traktowanie więźniów..., p. 286.

${ }^{45}$ Cf. T. Mommsen, Römisches Strafrecht, Leipzig 1899, p. 921; A. Lisiecki, Konstantyn Wielki, Poznań 1913, p. 123; B. Biondi, Il diritto romano cristiano, vol. 3, pp. 455-456.

46 Aurelius Victor, De ceasaribus 41,4-5: Denique Constantinus cunctos hostes honore ac fortunis manentibus texit recepitque, eo pius, ut etiam vetus teterrimumque supplicium patibulorum et cruribus suffringendis primus removerit.

47 Aug., Sermo 88,9: Sed quia ipse honoraturus erat fideles suos in fine huius saeculi, prius honoravit crucem in hoc saeculo; ut terrarum principes credentes in eum prohiberent aliquem nocentium crucifigi: et quod cum magna insultatione persecutores Iudaei Domino procurarunt, magna fiducia servi eius, etiam reges in fronte nunc portant. 
least one Constantine's constitution known, in which he ordered the crucifixion of slaves. ${ }^{48}$

It is also worth adding that the custom of proclaiming amnesty on the occasion of some Christian holidays established over time, including in particular Easter (Dies Paschalis). The earliest traces of this tradition, preserved in the Codex Theodosianus, come from the reign of Valentinian I, Valens and Gratian, ${ }^{49}$ although it is possible that such a practice may have existed before. The impact of Christianity on announcing amnesties during such holidays is quite obvious, ${ }^{50}$ although it is worth mentioning that its use was also an excellent method for reducing the extreme overcrowding in late Roman prisons. ${ }^{51}$

The intensification of criminal repression under the influence of Christianity could have taken place primarily in the moral sphere. However, generalising this phenomenon may lead to wrong conclusions. The Christian inspiration should be ruled out, for example, for the issue of imposing severe penalties on kidnappers for matrimonial purposes. ${ }^{52}$ The most famous sanction provided for in the constitution of Constantine the Great

48 C. Th. 9,5,1,1: In servis quoque vel libertis, qui dominos aut patronos accusare aut deferre temptaverint, professio tam atrocis audaciae statim in admissi ipsius exordio per sententiam iudicis comprimatur ac denegata audientia patibulo adfigatur. There is no mention on crucifixion in the later imperial legislation, cf. J. Harries, Law and Empire in Late Antiquity, Cambridge 2004, p. 138.

49 C. Th. 9,38,3: Ob diem paschae, quem intimo corde celebramus, omnibus, quos reatus adstringit, carcer inclusit, claustra dissolvimus. Adtamen sacrilegus in maiestate, reus in mortuos, veneficus sive maleficus, adulter raptor homicida communione istius muneris separentur.

50 Cf. U. Brasiello, Premesse relative allo studio dell'influenza del Cristianesimo sul diritto romano, in: Scritti in onore di Contardo Ferrini pubblicati in occasione della sua beatificazione, vol. 2, Milano 1947, p. 8; B. Biondi, Il diritto romano cristiano, vol. 3, p. 442; V. Giuffrè, La repressione criminale nell'esperienza romana, Napoli 1998, p. 171.

51 On the issue of overcrowded prisons cf. C. Kunderewicz, Traktowanie więźniów..., p. 283; A. Świętoń, Humanitaryzm..., p. 46.

${ }^{52}$ However, this issue was discussed in the literature on the topic. The first to suggest the Christian inspiration was J. Gothofredus, Codex Theodosianus cum perpetuis commentariis Iacobi Gothofredi, vol. 3, Lipsiae 1738, comm. ad C. Th. 9,24,1, p. 212. Later on, a view began to prevail that the constitution protected first and foremost the rights resulting from patria potestas - T. Mommsen, Römisches Strafrecht, p. 702; D. Grodzynski, Ravies et coupables. Un essai d'interprétation de la loi IX, 24, 1 du Code Théodosien, Mélanges de l'École Française de Rome. Antiquité 1984, vol. 96, no. 2, pp. 699-701; J. Evans-Grubbs, Abduction Marriage..., p. 79; J. Wiewiorowski, Porywanie kobiet jako zjawisko społeczne w późnym antyku. Moralność a prawo, in: Homo, qui sentit. Ból i przyjemność w średniowiecznej kulturze Wschodu i Zachodu, 
regarding this issue was reserved for the custodian of the kidnapped girl whose behaviour can be described as "obstruction of justice" involving false testimony to confuse the pursuit. The punishment consisted in pouring liquid lead into her throat (liquendis plumbi ingestio) and was of a symbolic nature (reflecting the offence) because in this situation the woman's mouth was a "weapon of crime." ${ }^{53}$ It is worth mentioning that the increase in the number of such penalties of a reflective nature that can be observed during this period is not attributable to Christianity, either. Apart from the aforementioned case, crimes thus punished were not related to the moral or even religious domain at all. ${ }^{54}$

However, the thesis about the influence of Christianity is likely in the case of intensification of criminal repression for adulterium, which can be observed in the legislation of Constantine the Great and later Constantius II and Constans. Constantine was the first to proclaim the death penalty for adulterium, ${ }^{55}$ which previously was a crime punishable by exile and confiscation of a half of the property. ${ }^{56}$ This is a reflection of views of Lactantius, who compared adulterers (adulterae) to poisoners (venefici) or gladiators (gladiatores), ${ }^{57}$ although, given the writer's general aversion

ed. J. Banaszkiewicz, K. Ilski, Poznań 2013, p. 211; V. Giuffrè, La repressione criminale..., p. 168.

53 C. Th. 9,24,1,1: Et quoniam parentum saepe custodiae nutricum fabulis et pravis suasionibus deluduntur, his primum, quarum detestabile ministerium fuisse arguitur redemptique discursus, poena immineat, ut eis meatus oris et faucium, qui nefaria hortamenta protulerit, liquentis plumbi ingestione claudatur.

54 This concerned such penalties as hand mutilation imposed on officials who demanded bribes for providing access to the judge (province governor) (C. Th. 1,16,7), tongue amputation (amputatio linguae) to delators (C. Th. 10,10,2), or feet amputation (amputatio pedum) applied to slaves who would escape outside the boundaries of the empire, alternative to the penalty of mine work (C. 6,1,3).

55 C. Th. 9,40,1: Qui sententiam laturus est, temperamentum hoc teneat, ut non prius capitalem in quempiam promat severamque sententiam, quam in adulterii vel homicidii vel maleficii crimine aut sua confessione aut certe omnium, qui tormentis vel interrogationibus fuerint dediti, in unum conspirantem concordantemque rei finem convictus sit et sic in obiecto flagitio deprehensus, ut vix etiam ipse ea, quae commiserit, negare sufficiat.

56 Cf. K. Amielańczyk, Crimina legitima w rzymskim prawie publicznym, Lublin 2013, p. 294; P. Csillag, The Augustan Laws on Family Relations, Budapest 1976, pp. 196-197.

57 Lactantius, Div. Inst. 5,20: Illic nihil exigitur aliud, quam sanguis pecudum, et fumus, et inepta libatio: hic, bona mens, purum pectus, innocens vita. Illuc veniunt sine delectu adulterae impudicae, lenae procaces, obscoenae meretrices; veniunt gladiatores, latrones, fures, venefici, et precantur nihil aliud, quam ut scelera impune committant. Quid enim latro sacrificans, aut gladiator 
to the death penalty in general, his direct influence on the intensification of repression in this respect should be ruled out. The solution introduced by the sons of Constantine - Constantius II and Constans, who ordered the use of the penalty of sack (poena cullei) against blatant adulterers, was even stricter. ${ }^{58}$ It can also be assumed that Christianity influenced the content of subsequent constitutions to protect women who devoted their lives to God. ${ }^{59}$

Particular consideration should be given to the seemingly most obvious issue. This is about the legislation on matters closely related to religion and aimed primarily at pagans and heretics. ${ }^{60}$ Confining the deliberations within the "short" $4^{\text {th }}$ century also in this case turns out to be a reasonable way of proceeding. The legislation aimed at pagan cults will also be an excellent example. It originally concerned the prohibition of domestic sacrifices and, as can be guessed, sacrifices associated with animal bloodshed. Emperor Constantine the Great allowed, and in some cases even recommended, the preservation of certain traditional rituals, for example, when lightning strikes a public building. ${ }^{61}$ The position of Constantius II, who in his constitution of 341 explicitly called for an end to the "madness of sacrifices" (sacrificiorum insania) under pain of an unspecified penalty,

roget, nisi ut occidant? Quid venenarius, nisi ut fallat? Quid meretrix, nisi ut plurimum peccet? Quid adultera, nisi ut mortem viri optet, aut ut sua impudicitia celetur? Quid lena, nisi ut multos bonis exuat? Quid fur, nisi ut plura compilet? Hic vero etiam levi communique peccato locus est nullus.

58 C. Th. 11,36,4: Oportuerat te publici instituti respectu confessione detectos legum severitate punire nec frustra vitam differentum moratorias provocationes admittere, sed delatum adulterii crimen et quaestionibus athibitis adprobatum pari sceleri immanitate damnare. Quod deinceps in huiusmodi criminibus convenit observari, ut manifestis probationibus adulterio probato frustratoria provocatio minime admittatur, cum pari similique ratione sacrilegos nuptiarum tamquam manifestos parricidas insuere culleo vivos vel exurere iudicantem oporteat.

59 C. Th. 9,25,1-2.

${ }^{60}$ Cf. J. Gaudemet, La formation..., p. 189.

61 C. Th. 16,10,1, pr.: Si quid de palatio nostro aut ceteris operibus publicis degustatum fulgore esse constiterit, retento more veteris observantiae quid portendat, ab haruspicibus requiratur et diligentissime scriptura collecta ad nostram scientiam referatur, ceteris etiam usurpandae huius consuetudinis licentia tribuenda, dummodo sacrificiis domesticis abstineant, quae specialiter prohibita sunt. 1. Eam autem denuntiationem adque interpretationem, quae de tactu amphitheatri scripta est, de qua ad Heraclianum tribunum et magistrum officiorum scripseras, ad nos scias esse perlatam. 
was more definitive. ${ }^{62}$ It should be presumed that this was still not the case with the death penalty, which appears clearly only in the constitutions of A.D. $356-357 .{ }^{63}$

Further constitutions aimed at pagan cults: prohibiting sacrifices, extispicy, and praising the deities with "ominous songs" (dira carmina) come from the period after A.D. 380. ${ }^{64}$ At the same time, a famous dispute arose over the removal of the altar of Victoria from the Roman Senate plenary chamber and the rejection of the title of supreme priest (pontifex maximus) by Emperor Gratian. ${ }^{65}$ Finally, in the constitution of 392 issued by Emperors Theodosius the Great and his sons Arcadius and Honorius, the sacrifice of animals and extispicy were considered crimen laese maiestatis. ${ }^{66}$

However, Emperor Honorius allowed for the celebration of traditional holidays, as long as it did not entail the pagan cults. ${ }^{67} \mathrm{He}$ also prohibited the demolition of temples devoid of altars and statues. ${ }^{68}$ Those regulations

62 C. Th. 16,10,2: Cesset superstitio, sacrificiorum aboleatur insania. Nam quicumque contra legem divi principis parentis nostri et hanc nostrae mansuetudinis iussionem ausus fuerit sacrificia celebrare, competens in eum vindicta et praesens sententia exeratur.

63 C. Th. 16,10,4: Placuit omnibus locis adque urbibus universis claudi protinus templa et accessu vetito omnibus licentiam delinquendi perditis abnegari. Volumus etiam cunctos sacrificiis abstinere. Quod si quis aliquid forte huiusmodi perpetraverit, gladio ultore sternatur. Facultates etiam perempti fisco decernimus vindicari et similiter adfligi rectores provinciarum, si facinora vindicare neglexerint. C. Th. 16,10,6: Poena capitis subiugari praecipimus eos, quos operam sacrificiis dare vel colere simulacra constiterit.

64 C. Th. 16,10,7-25.

65 P. Chuvin, Ostatni poganie. Zanik wierzeń pogańskich w cesarstwie rzymskim od Konstantyna do Justyniana, transl. J. Stankiewicz-Prądzyńska, Warszawa 2008, pp. 72-73. The altar had been removed by the order of Constantius II but probably returned to the building of the Senate during the reign of Julian the Apostate, cf. A. Cameron, Późne cesarstwo..., p. 91.

${ }^{66}$ C. Th. 16,10,12,2: Quod si quispiam immolare hostiam sacrificaturus audebit aut spirantia exta consulere, ad exemplum maiestatis reus licita cunctis accusatione delatus excipiat sententiam competentem, etiamsi nihil contra salutem principum aut de salute quaesierit. Sufficit enim ad criminis molem naturae ipsius leges velle rescindere, illicita perscrutari, occulta recludere, interdicta temptare, finem quaerere salutis alienae, spem alieni interitus polliceri.

67 C. Th. 16,10,17: Ut profanos ritus iam salubri lege submovimus, ita festos conventus civium et communem omnium laetitiam non patimur submoveri. Unde absque ullo sacrificio atque ulla superstitione damnabili exhiberi populo voluptates secundum veterem consuetudinem, iniri etiam festa convivia, si quando exigunt publica vota, decernimus.

68 C. Th. 16,10,18: Aedes illicitis rebus vacuas nostrarum beneficio sanctionum ne quis conetur evertere. Decernimus enim, ut aedificiorum quidem sit integer status, si quis vero in sacrificio fuerit deprehensus, in eum legibus vindicetur, depositis sub officio idolis disceptatione habita, quibus etiam nunc patuerit cultum vanae superstitionis impendi. 
probably initially concerned only Proconsular Africa but one can guess that wherever rural pagan traditions were still alive, they were allowed to continue, of course, in the form stripped of sacred elements and reduced to the role of a kind of folklore.

The first laws against heretics, or more correctly schismatics, were issued by Constantine the Great, and they concerned mainly Donatists. This religious movement was not characterised by a particularly heretical nature in terms of teaching but the essence of the controversy was disciplinary in nature and concerned the attitude towards people who gave out holy books to the Roman authorities during the persecution. ${ }^{69}$ Constantine's policy towards Donatists was quite complex and was changing along various periods. ${ }^{70}$ The emperor even issued a constitution that was supposed to force them to abandon their erroneous concepts but he eventually withdrew from it as can be seen from a letter from the emperor. ${ }^{71}$ Another heretical group was treated by Constantine rather gently. It is about Novatians who were allowed to keep their own buildings and

69 The notions of heresy and schism were not precisely distinguished in this period. According to A. Dębiński, heresy is a controversy of a doctrinal nature, while schism - of a disciplinary nature, cf. A. Dębiński, Herezja jako przestępstwo prawa rzymskiego, in: "Salus rei publicae suprema lex". Ochrona interesów państwa w prawie karnym starożytnej Grecji i Rzy$m u$, ed. A. Dębiński, H. Kowalski, M. Kuryłowicz, Lublin 2007, pp. 45-46. More on the Roman policy toward heretical groups cf. M. Stachura, Heretycy, schizmatycy i manichejczycy wobec cesarstwa rzymskiego (lata 324-428, wschodnia część Imperium), Kraków 2000.

70 More on this topic cf.: T.D. Barnes, The Beginnings of Donatism, The Journal of Theological Studies 1975, vol. 26, no. 1, pp. 13-22; T. Kołosowski, Polityka religijna Konstantyna Wielkiego w świetle schizmy donacjańskiej, Saeculum Christianum. Pismo Historyczno-Społeczne 1995, vol. 2, no. 1, pp. 17-37; S. Bralewski, Uwagi na temat antyheretyckiego ustawodawstwa cesarza Konstantyna Wielkiego, Przegląd Nauk Historycznych 2002, no. 1, pp. 7-20. Constantine's legislative policy in religious matters is described in detail by J. Gaudemet, cf. idem, La législation religieuse de Constantin, Revue d'Histoire de l'Église de France 1947, vol. 33, no. 122, pp. 25-61.

71 Optatus, Contra Don., App. IX. Louis Duchesne supposes that this letter was written in A.D. 321, cf. L. Duchesne, Le dossier du donatisme, Mélanges d'Archéologie et d'Histoire 1890, vol. 10, p. 611. The authenticity of the letter was challenged by O. Seeck, who nonetheless - under the Duchesne's argumentation - revised his views in part, cf. O. Seeck, Quellen und Urkunden über die Anfünge des Donatismus, Zeitschrift für Kirchengeschichte 1889, no. 10, pp. 505-568; idem, Urkundenfälschungen des 4. Jahrhunderts (1. Hälfte), Zeitschrift für Kirchengeschichte 1909, vol. 30, pp. 181-227. As T.D. Barnes states, it has eventually been decided that there is no ground to doubt the authenticity of Constantine's correspondence kept by Optatus, cf. T.D. Barnes, The Beginnings of Donatism, pp. 13-14. 
cemeteries. ${ }^{72}$ In the constitution from 326 addressed to Dracilian, who was responsible for the construction of the Church of the Saviour in Jerusalem, the emperor took a more general stance on heretics and schismatics not listed by name. ${ }^{73}$ He stated that they should be deprived of the privileges of Catholics and should bear public burdens, as confirmed by his earlier provision contained in the constitution from $313 .{ }^{74}$ Jean Gaudemet rightly points out that similar legal remedies were not extended to other religions, and therefore pagan priests were not deprived of their privileges by Constantine. ${ }^{75}$ In relation to Jewish communities those privileges were even confirmed ${ }^{76}$ although at the same time Jews were allowed to municipal curiae, ${ }^{77}$ which entailed various public burdens. ${ }^{78}$

Constantine's policy towards heretical and schismatic groups has undergone evolution to eventually abandon the use of violence. As S. Bralewski notes, the emperor was inclined to make concessions, as long as he could achieve his fundamental political objective of the unity of

72 C. Th. 16,5,2: Novatianos non adeo comperimus praedamnatos, ut his quae petiverunt crederemus minime largienda. Itaque ecclesiae suae domos et loca sepulcris apta sine inquietudine eos firmiter possidere praecipimus, ea scilicet, quae ex diuturno tempore vel ex empto habuerunt vel qualibet quaesiverunt ratione. Sane providendum erit, ne quid sibi usurpare conentur ex his, quae ante discidium ad ecclesias perpetuae sanctitatis pertinuisse manifestum est.

73 C. Th. 16,5,1: Privilegia, quae contemplatione religionis indulta sunt, catholicae tantum legis observatoribus prodesse oportet. Haereticos autem atque schismaticos non solum ab his privilegiis alienos esse volumus, sed etiam diversis muneribus constringi et subici.

74 C. Th. 16,2,1: Haereticorum factione comperimus ecclesiae catholicae clericos ita vexari, ut nominationibus seu susceptionibus aliquibus, quas publicus mos exposcit, contra indulta sibi privilegia praegraventur. Ideoque placet, si quem tua gravitas invenerit ita vexatum, eidem alium subrogari et deinceps a supra dictae religionis hominibus huiusmodi iniurias prohiberi.

75 J. Gaudemet, La législation religieuse..., p. 61.

76 C. Th. 16,8,2: Qui devotione tota synagogis iudaeorum patriarchis vel presbyteris se dederunt et in memorata secta degentes legi ipsi praesident, inmunes ab omnibus tam personalibus quam civilibus muneribus perseverent, ita ut illi, qui iam forsitan decuriones sunt, nequaquam ad prosecutiones aliquas destinentur, cum oporteat istiusmodi homines a locis in quibus sunt nulla compelli ratione discedere. Hi autem, qui minime curiales sunt, perpetua decurionatus immunitate potiantur. C. Th. 16,8,4: Hiereos et archisynagogos et patres synagogarum et ceteros, qui synagogis deserviunt, ab omni corporali munere liberos esse praecipimus.

77 C. Th. 16,8,3: Cunctis ordinibus generali lege concedimus iudaeos vocari ad curiam. Verum ut aliquid ipsis ad solacium pristinae observationis relinquatur, binos vel ternos privilegio perpeti patimur nullis nominationibus occupari.

78 Cf. G. Alföldy, The Social History of Rome, transl. D. Braund, F. Pollock, Baltimore 1988, pp. 201-202. 
the Church in religious terms. ${ }^{79}$ The attitude to heretical groups radically changed under the reign of the Valentinian-Theodosian dynasty. The imperial constitutions from the 370 s even provided for forfeitures of heretical sites of worship to the state treasury, the prohibition of assembly for heretics, and various other restrictions. ${ }^{80}$ Most constitutions aimed against heretical groups came from the period after 380. At this time, the death penalty for Manicheans ${ }^{81}$ was also provided for, which was a departure from the general rule of not applying the capital punishment against the heretics. ${ }^{82}$ All in all, this was in line with the postulates put forward by Christian writers such as Saint Nicholas, John Chrysostom or Saint Augustine. ${ }^{83}$ The Bishop of Hippo postulated to encourage the heretics to correct themselves, not to punish them with death. ${ }^{84}$ Eventually, heresy was unequivocally recognised as a crime of public law only in 407, under the Constitution of the Emperor Arcadius and Emperor Honorius. ${ }^{85}$

A large number of constitutions aimed at heretics suggest that the problem was serious and that most of the legal remedies against it remained ineffective. ${ }^{86}$ It also seems that religious considerations were not at all the only reasons to lead the emperors to combat heresy. Equally important

79 S. Bralewski, Uwagi na temat..., pp. 19-20.

80 This concerns infamy, penalty of exile, prohibition of holding official posts, restrictions in the sphere of private law, cf. A. Dębiński, Ustawodawstwo karne rzymskich cesarzy chrześcijańskich w sprawach religijnych, Lublin 1990, pp. 92 ff.

81 C. Th. $16,5,9$.

82 A. Dębiński, Ustawodawstwo karne..., p. 88.

83 Idem, Kara śmierci..., pp. 50-51.

84 Aug., Ep. 100: Quaesumus igitur ut cum Ecclesiae causas audis, quamlibet nefariis iniuriis appetitam vel afflictam esse cognoveris, potestatem occidendi te habere obliviscaris, et petitionem nostram non obliviscaris. Non tibi vile sit, neque contemptibile, fili honorabiliter dilectissime, quod vos rogamus ne occidantur, pro quibus Dominum rogamus ut corrigantur. Excepto etiam quod a perpetuo proposito recedere non debemus vincendi in bono malum; illud quoque prudentia tua cogitet, quod causas ecclesiasticas insinuare vobis nemo praeter ecclesiasticos curat. Proinde, si occidendos in his sceleribus homines putaveritis, deterrebitis nos ne per operam nostram ad vestrum iudicium aliquid tale perveniat: quo comperto illi in nostram perniciem licentiore audacia grassabuntur, necessitate nobis impacta et indicta, ut etiam occidi ab eis eligamus, quam eos occidendos vestris iudiciis ingeramus.

85 C. Th. 16,5,40,1: Ac primum quidem volumus esse publicum crimen, quia quod in religionem divinam conmittitur, in omnium fertur iniuriam.

86 There are 66 constitutions against heretics preserved in the Codex Theodosianus, cf. C. Th. 16,5. However, certainly these are not all legal acts issued against these religious groups between 313 and 437 . 
was the need to ensure public order and security, put at risk by any controversy by increasing the risk of riots, mob rule, and even arsons and attacks on "adversary" sites of worship. ${ }^{87}$ Jean Gaudemet, when analysing the legislative activity of Constantine the Great in religious matters, stated that the reasons this ruler was guided by were more of a political nature than a religious one ${ }^{88}$ In part, this thesis can be applied to the later emperors, although the proportions seem to have gradually reversed and the religious element began to dominate over time.

Concluding, it should be stressed that the phenomenon in question was extremely complex. One must first refer to the humanisation of certain solutions known to the Roman criminal law. In this respect, on the one hand, it could be seen that the increasingly influential representatives of Christianity drew on the achievements of pagan writers, giving new content to well-known concepts such as humanitas. On the other hand, pagan intellectuals often joined the voice of Christians, the prime example of which could be the argumentation of Libanius who postulated the improvement of conditions in prisons. It must be added that many humanitarian solutions also have a propaganda connotation, serving to confirm the image of the emperors as "restorers of human kind" (restitutores humani generis). ${ }^{89}$ Those and other similar terms (humanarum rerum optimus princeps or omnia quae humani generis societate tuentur), stressing the ruler's virtues and the universal and kind-hearted nature of his reign, had to be reflected in at least some of legal acts. ${ }^{90}$

It is even more difficult to define the influence of Christianity on intensification of severity of Roman law. Christianity has certainly influenced the emergence of new religious crimes, especially the crime of heresy. Given the general severity of the Roman criminal law during that period, the criminal sanctions applicable for heresy must nevertheless be considered relatively benign. A much stricter penal repression affected the gentiles. Although the gentiles participated in public life still for a long time, holding very high functions even under the rule of Theodosius the Great,

87 This was noticeable also with regard to pagan temples, cf. A. Cameron, Późne cesarstwo..., pp. 92-93.

88 J. Gaudemet, La législation religieuse..., p. 61.

89 Cf. e.g. CIL VI, 1140 (ILS 692).

90 Cf. D. Gorostidi Pi, O. Olesti Vila, R.A. Expósito, La función propagandística de la epigrafía bajo Constantino: el caso de los miliarios catalanes, in: Constantino. El primer emperador cristiano? Religión y política en el siglo IV, Barcelona 2015, p. 360. 
the final crackdown with the public pagan worship took place at the end of the $4^{\text {th }}$ century. However, paganism maintained its vitality for a long time and the penal measures used in this respect were quite ineffective, especially as they covered with the scope of penalisation mainly the offering of sacrifices. ${ }^{91}$

In general terms, however, Christianity did not affect the intensity of the repressive nature of the Roman criminal law during the period in question. Peter Garnsey, who points here rather to political, systemic and social considerations, is right. ${ }^{92}$ This should be also juxtaposed with organisational difficulties of the late-Roman administration, the primary purpose of which was the absolute enforcement of tax debts to fund the army, the size of which increased under the rule of Diocletian and Constantine. ${ }^{93}$ Therefore, religious considerations, although probably much more important than today, could not have a decisive influence on the main trends in the criminal policy of successive Roman emperors in the $4^{\text {th }}$ century.

\section{Bibliography}

Alföldy G., The Social History of Rome, transl. D. Braund, F. Pollock, Baltimore 1988. Amielańczyk K., Crimina legitima w rzymskim prawie publicznym, Lublin 2013.

Barnes T.D., Athanasius and Constantius. Theology and Politics in the Constantinian Empire, London 2001.

Barnes T.D., Constantine and Eusebius, London 1996.

Baviera G., Concetto e limiti dell'influenza del Cristianesimo sul diritto romano, in: Mélanges P.F. Girard, vol. 1, Paris 1912.

Biondi B., Il diritto romano cristiano, vol. 1-3, Milano 1952-1954.

Bralewski S., Uwagi na temat antyheretyckiego ustawodawstwa cesarza Konstantyna Wielkiego, Przegląd Nauk Historycznych 2002, no. 1.

91 Averil Cameron notes that mighty pagan families can be still found in the $6^{\text {th }}$ century, cf. A. Cameron, Późne cesarstwo..., p. 92. Also G. Alföldy states that the ancient tradition with Christian world-view became reconciled as late as in the $6^{\text {th }}$ century, cf. G. Alföldy, The Social History ..., p. 199.

92 P. Garnsey, Why Penalties..., p. 161.

93 Cf. A. Cameron, Późne cesarstwo..., pp. 132, 170-172. 
Brasiello U., Premesse relative allo studio dell'influenza del Cristianesimo sul diritto romano, in: Scritti in onore di Contardo Ferrini pubblicati in occasione della sua beatificazione, vol. 2, Milano 1947.

Cameron A., Późne cesarstwo rzymskie, transl. M. Kwiecień, Warszawa 2005.

Carusi E., Diritto romano e patristica, in: Studi giuridici in onore di Carlo Fadda pel 25. anno del suo insegnamento, vol. 2, Napoli 1906.

Dębiński A., Church and Roman Law, transl. K. Szulga, Lublin 2010.

Dębiński A., Kara śmierci w świetle literatury wczesnochrześcijańskiej, in: Religia i prawo karne w starożytnym Rzymie, ed. A. Dębiński, M. Kuryłowicz, Lublin 1998.

Dębiński A., Ustawodawstwo karne rzymskich cesarzy chrześcijańskich w sprawach religijnych, Lublin 1990.

Evans-Grubbs J., Abduction Marriage in Antiquity: A Law of Constantine (CTh IX. 24. 1) and Its Social Context, The Journal of Roman Studies 1989, vol. 79.

Farina R., L'Impero e l'Imperatore cristiano in Eusebio di Cesarea. La prima teologia politica del cristianesimo, Roma-Zürich 1966.

Frare M., L'humanitas romana. Vessillo del potere imperiale, Padova 2013.

Garnsey P., Why Penalties Become Harsher: The Roman Case, Late Republic to Fourth Century Empire, Natural Law Forum 1968, 1/1.

Garofalo L., L' "humanitas" nel pensiero della giurisprudenza classica, in: L'humanitas nel mondo antico: filantropia, cultura, pietas. Convegno nazionale di studi, Chiesa S. Croce in San Leonardo all'Università, 22 novembre 2003, Treviso 2003.

Gaudemet J., La formation du droit séculier et du droit de l'Église aux IVe et Ve siècles, Paris 1957.

Gaudemet J., L'Église dans l'Empire romain (IV-V siècles), Paris 1958.

Geanakoplos D.J., Church Building and "Caesaropapism," A.D. 312-565, Greek, Roman and Byzantine Studies 1966, vol. 7, no. 2.

Giuffrè V., La repressione criminale nell'esperienza romana, Napoli 1998.

Gothofredus J., Codex Theodosianus cum perpetuis commentariis Iacobi Gothofredi, vol. 3, Lipsiae 1738.

Gray C., Il diritto nel Vangelo e l'influenza del cristianesimo sul diritto romano, Torino 1922.

Harries J., Law and Empire in Late Antiquity, Cambridge 2004.

Hillner J., Prison, Punishment and Penance in Late Antiquity, Cambridge 2015.

Kaser M., Borys Łapicki. Etyczna kultura starożytnego Rzymu a wczesne chrześcijaństwo (La culture éthique de la Rome ancienne et les premiers temps du christianisme). Łódź, Ossoliński, 1958. 322 S. [review], Zeitschrift der Savigny-Stiftung für Rechtsgeschichte. Romanistische Abteilung (1959), vol. 76.

Krüger H., Die humanitas und die pietas nach den Quellen des römischen Rechtes, Zeitschrift der Savigny-Stiftung für Rechtsgeschichte. Romanistische Abteilung 1898, vol. 19, no. 1 . 
Kubiak P., Damnatio ad bestias i inne kary wykonywane na arenie w antycznym Rzymie, Łódź 2014.

Kumor B., Historia Kościoła, vol. 1. Starożytność chrześcijańska, Lublin 1973.

Kunderewicz C., Traktowanie więźniów w konstytucjach cesarskich z okresu dominatu,

Prawo Kanoniczne. Kwartalnik Prawno-Historyczny 1977, vol. 20, no. 3/4.

Kupiszewski H., Prawo rzymskie a wspótczesność, Kraków 2013.

Liebs D., Das Recht der Römer und die Christen, Tübingen 2015.

Lovato A., Il carcere nel diritto penale romano. Dai Severi a Giustiniano, Bari 1994.

Łapicki B., Etyczna kultura starożytnego Rzymu a wczesne chrześcijaństwo, WrocławŁódź 1958.

Łapicki B., O spadkobiercach ideologii rzymskiej. Okres chrystianizacji cesarstwa rzymskiego, Łódź 1962.

Marchi A., Dell'influenza del cristianesimo sulla Codificazione Giustinianea, Studi Senesi 1924, vol. 38.

Maschi C.A., "Humanitas" come motivo giuridico, in: Scritti in memoria di Luigi Cosattini, Trieste 1948.

Merkwa M., U źródeł idei praw człowieka. Kształtowanie prawnych i filozoficznych podstaw koncepcji praw człowieka, Lublin 2018.

Mommsen T., Römisches Strafrecht, Leipzig 1899.

Palma A., Humanior interpretatio: "Humanitas" nell'interpretazione e nella normazione da Adriano ai Severi, Torino 1992.

Paribeni R., Storia di Roma, vol. 8. Da Diocleziano alla caduta dell'impero d'occidente, Bologna 1941.

Potter D., Constantine and the Gladiators, Classical Quarterly 2010, vol. 60, no. 2.

Purpura G., Brevi riflessioni sull' "humanitas", Annali del Dipartimento di Storia del Diritto dell'Università di Palermo 2009, vol. 53.

Riccobono S. (Jr.), L'idea di "humanitas" come fonte di progresso del diritto, in: Studi in onore di Biondo Biondi, vol. 2, Milano 1965.

Riccobono S. (Sr.), Cristianesimo e diritto privato, Rivista di Diritto Civile 1911, no. 3.

Riccobono S. (Sr.), Influenza del Cristianesimo sulla codificazione di Giustiniano, Scientia 1909, vol. 5, no. 3 .

Sadowski P., Constantin le Grand et les gladiateurs. Autour de la constitution impériale affichée à Beyrouth (C. Th. 15,12,1), in: Niš and Byzantium: Twelfth Symposium, Niš, 3-6 June 2013 [the collection of scientific works XII], Niš 2014.

Salerno F., "Minime in ... facie scribatur": Constantine and the "damnati ad metalla", in: Esclavage antique et discriminations socio-culturelles, ed. V.I. Anastasiadis, P.N. Doukellis, Berne-New York 2005.

Schmitt C., Politische Theologie II. Die Legende von der Erledigung jeder Politischen Theologie, Berlin 2017.

Świat rzymski w IV w., ed. P. Filipczak, R. Kosiński, Kraków 2015. 
Świętoń A., Humanitaryzm w rzymskim późnoantycznym ustawodawstwie cesarskim na przyktadzie konstytucji zamieszczonych w CTh 9.3. "De custodia reorum", Studia Prawnoustrojowe 2009, vol. 9.

Tarwacka A., O tym, że termin "humanitas" nie oznacza tego, co się powszechnie sadzi, natomiast ci, którzy mówili czystszym językiem, używali go bardziej właściwie. Aulus Gellius, "Noce attyckie" 13,17. Tekst - ttumaczenie - komentarz, Zeszyty Prawnicze 2015, vol. 15, no. 2.

Troplong R.T., De l'influence du christianisme sur le droit civiles des Romains, Paris 1855. Veyne P., Humanitas: Romans and Non-Romans, in: The Romans, ed. A. Giardina, transl. L. Cochrane, Chicago 1993.

Veyne P., Païens et chrétiens devant la gladiature, Mélanges de l'École Française de Rome 1999, vol. 111, no. 2.

Veyne P., Qu'était-ce qu'un empereur romain?, Diogène 2002, vol. 199, no. 3.

Ville G., La gladiature en Occident des origines à la mort de Domitien, Rome 1981.

Volterra E., Quelques remarques sur le style des constitutions de Constantin, in: Droits de l'Antiquité et sociologie juridique: Mélanges Henri Léry-Bruhl, Paris 1959.

Wiewiorowski J., Porywanie kobiet jako zjawisko społeczne w późnym antyku. Moralność a prawo, in: Homo, qui sentit. Ból i przyjemność w średniowiecznej kulturze Wschodu i Zachodu, ed. J. Banaszkiewicz, K. Ilski, Poznań 2013.

Wiewiorowski J., The Judiciary of Diocesan Vicars in the Later Roman Empire, transl. S. Nowak, Poznań 2015.

Wipszycka E., Kościót w świecie późnego antyku, Warszawa 1994.

Wójcik M., Cesarz w Kościele czy ponad Kościołem? Relacje między imperium a sacerdotium w IV wieku, in: Romanitas et Christianitas. Stanislao Płodzień (1913-1962) in memoriam, ed. A. Dębiński, S. Jóźwiak, Lublin 2008.

Wubbe F.B.J., L'“humanitas" de Justinien, Tijdschrift voor Rechtsgeschiedenis 1990, vol. 58 , no. 3 .

Zalewski B., Inspiracje filozoficzne i religijne dla zakazu piętnowania twarzy skazańców. Ze studiów nad konstantyńską humanitas, Czasopismo Prawno-Historyczne 2017, vol. 69, no. 2.

\section{Summary}

The article synthetically presents the main directions of the possible influence of Christianity on the Roman criminal law, which are characterised by two mutually opposing tendencies: intensification and alleviation of penal repression. However, one cannot overestimate the influence of Christianity on the Roman criminal law of the period in question, covering the years 313-380. Christianity did not have a fundamental impact on the imperial legislation during that period 
and did not contribute to the discontinuation of the trends already occurring in the period of the late Principate.

Key words: Christianity, Roman criminal law, humanitas, severitas

\section{HUMANITAS I SEVERITAS. O MOŻLIWYCH WPEYWACH CHRZEŚCIJAŃSTWA NA RZYMSKIE PRAWO KARNE W IV WIEKU}

\section{Streszczenie}

Artykuł w syntetyczny sposób prezentuje główne kierunki możliwych wpływów chrześcijaństwa na rzymskie prawo karne, przejawiające się w dwu przeciwstawnych tendencjach: wzmożenia oraz złagodzenia represji karnej. Wpływów chrześcijaństwa na rzymskie prawo karne w omawianym okresie, obejmującym lata 313-380, nie można jednak przeceniać. Chrystianizm nie wywarł zasadniczego wpływu na prawodawstwo cesarskie w tym okresie i nie przyczynił się do przełamania tendencji występujących już w okresie późnego pryncypatu.

Słowa kluczowe: chrześcijaństwo, rzymskie prawo karne, humanitas, severitas

\section{HUMANITAS И SEVERITAS. \\ О ВОЗМОЖНОМ ВЛИЯНИИ ХРИСТИАНСТВА НА РИМСКОЕ УГОЛОВНОЕ ПРАВО В ЧЕТВЕРТОМ ВЕКЕ}

Рез оме

В статье синтетически представлены основные направления возможного влияния христианства на римское уголовное право, проявляющиеся в двух противоположных тенденциях: усиление и смягчение криминальных репрессий. Однако влияние христианства на римское уголовное право в этот период, охватывающий 313-380 годы, нельзя переоценивать. Христианство не оказало существенного влияния на императорское законодательство в этот период и не способствовало преодолению тенденций, существовавших уже в период позднего принципата.

Ключевые слова: христианство, римское уголовное право, humanitas, severitas 